\title{
TAKAFUL OPERATORS' CORPORATE SOCIAL PERFORMANCE (CSP): AN INDUSTRY PERSPECTIVE
}

\author{
Amirul Afif Muhamat, Mohamad Nizam Jaafar, Sharifah Faigah Syed Alwi \\ Faculty of Business Management, Universiti Teknologi MARA
}

\begin{abstract}
Takaful operators which are part of Islamic financial institutions (IFIs) derive their fundamental principles from shariah. These religious based institutions are expected to fulfill the two important roles in their business operations: commercially profitable and socially responsible. Nevertheless, their societal role is rarely measured and discussed. Therefore, this study appraised the societal role of takaful operators by assessing the components which have been proposed under the corporate social performance (CSP) theme for IFIs. This study has arranged structured interview sessions with the Chief Investment Officers and Heads of Investment of each of the eleven takaful operators in Malaysia. The Delphi-style technique was adopted when developing the interview questions. The questions were developed in the form of a five-point Likert scale, addressing specific issues on CSP of takaful operators. In addition, information on takaful operators' CSR activities, zakat and tax payment were gathered from the companies' websites and annual report of takaful operators. The study concludes that takaful operators in Malaysia have achieved their societal role through two channels: CSP programmes financed from companies' profits and fulfillment of CSP as a result of business-community agenda. This study covers every takaful operator in Malaysia and the results reflect industry opinion.
\end{abstract}

Keywords: Takaful operator, Takaful, corporate social performance, Islamic insurance, Islamic financial institution

\section{INTRODUCTION}

Takaful embraced the concepts of mutual assistance and brotherhood by bearing each other risk in the event of calamity (Gönülal 2012; Siddiqui \& Hunt-Ahmed 2013). Over the years, the scheme which was started as community based initiative is now seen as a lucrative business sector, as part of the Islamic finance industry. The takaful sector is expected to achieve USD 20 billion in term of gross contribution by 2017 (The World Takaful Report 2014). In Malaysia, the sector is forecasted to achieve nearly USD 5 billion in 2016 (Malaysian Takaful Association 2014).

Takaful operators which are part of Islamic financial institutions (IFIs), derive their fundamental principles from shariah. These religious based institutions are expected to fulfil the two important roles in their business operations by being commercially profitable and socially responsible.

This research argues that for contribution towards the society, such performance is categorized as corporate social performance (CSP) of takaful operators which is received limited attention 
compared to financial performance of takaful operators. Therefore, this study appraised the societal role of takaful operators by assessing their CSP components as suggested in previous literature for the IFIs.

The structure of this paper after this introduction section is review on the philosophy and principles of takaful. Next is overview on takaful operators in Malaysia, followed by discussion on takaful operators' CSP, research method, findings and conclusion.

\section{Philosophy and Principles of Takaful}

Takaful early practices were dated back to a system known as aqilah which provides compensation by paying money to the victim's family (Alhabshi \& Razak 2011). This scheme was initiated by pooling money (diyyah) purposely to compensate for the unintentional injury or death caused by member of a particular tribe to other tribes. Interestingly, this has been practiced even before the advent of Islam. Therefore, instead of 'compensation' was decided on the battlefield which was normally practiced during that time, takaful scheme in form of aqilah model has managed to some extent to avoid the instigation of tribal war - as a peaceful option for them (Engku Ali, Odierno \& Ismail 2008; Swartz \& Coetzer 2010).

With the spread of Islam and acceptance of the faith by the Arabs, some of the early practices were retained, since they were compatible with Islam. Takaful was then developed during the Prophet Muhammad (pbuh) and his companions period, and such practices were continued by various Islamic dynasties from Umayyad, Abbasid, and lastly the Ottomans (Pamuk 2004; Wilson 2008; Çizakça 2011; Kuran 2012).

Tabarru' (donation) is the underpinning element that differentiates takaful from conventional insurance. This is because the former business operates on a risk sharing basis, whereas the latter provides risk transfer (Wahab, Lewis \& Hassan 2007; Bakar 2011). Tabarru' will relinquish takaful contributors' claims on the fund as it is considered a gratuitous contract ${ }^{*}$ and not a sale contract. The tabarru' fund also known as premium, contributed by the takaful contributors and segregated into two main accounts: Participant Special Account (PSA), or the risk fund, and Participant Account (PA), or the investment fund.

The basic principles in takaful policy are equivalent to the conventional insurance, albeit with some philosophical differences as explained earlier. A potential takaful contributor (policyholder) is expected to exhibit the features of basic insurance (takaful) principles in order to be eligible to sign a takaful policy or contract. Hassan (258: 2014) describes six basic principles which must exist before a person takes up a takaful policy: utmost good faith; insurable interest; indemnity; proximate cause; beneficiary issue; and underwriting. In spite of philosophical differences as explained earlier, the basic principles in takaful policy are equivalent to the conventional insurance.

\footnotetext{
*Engku Ali, Odierno and Ismail (2008) clarify that tabarru' has caused the takaful transaction to be permissible according to Shariah, since it changes the basis of insurance contract from an exchange contract which is bilateral in nature to a charitable contract which is unilateral in nature. Being a charitable contract, the takaful contributors are not aiming for profit from uncertainty, rather they intend to pool sufficient funds to be used for assisting other members in case of misfortune.
} 


\section{Takaful Operators in Malaysia}

First takaful operator in Malaysia was established in 1984, and since then, the industry has gone through rapid development by having 12 takaful operators operating side by side the conventional insurance companies. The numbers then dropped to 11 takaful operators when merger and acquisition (M\&A) process took place between AIA and ING operations in Malaysia (ING Website 2012). Takaful operators are not only competing amongst themselves for the same market, but also neck-to-neck with conventional insurance companies in a dual financial system landscape. This situation caused stiff competition amongst the market players; however it promotes better services and products for the customers. There are five basic takaful models in the world, which are ta'awuni (cooperation), mudharabah (profit sharing), wakalah (agency), waqf (endowment) and hybrid. Each model has its own features and limitations. In Malaysia, the wakalah model is adopted by every takaful operator which have been customized to meet specific needs of takaful operators' products (Htay \& Zaharin 2012). The wakalah model compared to other models is capable to realize the commercial objective of takaful operators, less controversial from shariah point of view and it can be combined with other takaful model (hybrid model) to make it flexible for other purpose like investment (Wahab, Lewis \& Hassan 2007; Mohd Kassim 2012).

\section{Takaful operators' corporate social performance (CSP)}

Much has been debated on the periphery of corporate social performance (CSP) in the Western literature and such positive vibes transmitted to the Islamic business. Accordingly, takaful companies which derived their philosophical foundation from Islam should behave parallel with the religion's teaching (Asutay 2008; Dar 2012). Islam views the use of profit for society's needs is preferable compared to individual consumption (Siddiqi 1981; Metwally 1997). It even has higher priority than the state (Cantori \& Lowrie 1992). In this particular context, firms have to be aware that their achievements are not measured alone in term of financial performance; rather the greatest achievement is when the firms can use their profits for the betterment of the society. Raghib (1995) suggests that profit is closely associated with business performance; but it should not be the only factor that firms consider since there are other responsibilities which firms need to reflect. This consistent with Ibn Khaldun comments that "...economic endeavour must generate income to market actors and enable and motivate them to serve their community," cited in Ali, Al-Aali and Al-Owaihan (2012).

Most of the literature discuss CSP within the periphery of corporate social responsibility (CSR) practiced by the companies. This assumption is partially accurate as Frederick (1994) emphasises that CSP is beyond that; and CSR is part and parcel of the CSP broad agenda. He suggested three steps which need to be fulfilled before the company can be regarded as achieving its CSP: CSR ${ }_{1}$; $\mathrm{CSR}_{2}$; and $\mathrm{CSR}_{3}$. Sairally (2013) describes $\mathrm{CSR}_{3}$ as the companies' CSP which eventually achieved after formulating the strategies and plans in $\mathrm{CSR}_{1}$, and implementing the ideas which described as $\mathrm{CSR}_{2}$. Carroll (1979) concisely describes $\mathrm{CSR}_{1}$ as the companies tasks to realize their duties: legal, ethical, economic and discretionary responsibilities. There are four components under $\mathrm{CSR}_{1}$ which are legal, ethical, economic and discretionary responsibilities as suggested by Carroll (1979). Companies have to plan for strategies and programs under each theme before they can implement them in the next level, $\mathrm{CSR}_{2}$. This specific components help to 
bring focus on the wide concept of CSR which Frederick (1994) describes as the implementable and measurable tasks.

The economic responsibilities deemed as the basic or first layer requirement of companies as business entities which required to provide goods and services needed by the society and expected to be profitable at the end of the process. Every other business roles are assigned to this function. The next function is legal responsibilities regarded as the framework which the society expected the companies to be operated by adhering to the rules and regulations imposed on them. After that is ethical responsibilities which described as the extension of the early two responsibilities (economic and legal) which are actually expected to be exercised ethically; however the difference under this precept is the society expects the companies to be ethically responsible beyond the prescribed ethics in the early two responsibilities. Lastly, the discretionary responsibilities, which are ethical actions that above the ethical responsibilities. This is exercised by the companies voluntarily, which even the society does not expect the companies to fulfil this. Carroll (1979: 500) gives instances on companies' contributions on this aspect such as day care for the working mothers and training for the unemployed people.

In term of $\mathrm{CSR}_{2}$ which Frederick (1994) describes it as corporate social responsiveness, dubbed as the managerial responds towards the precepts laid down in $\mathrm{CSR}_{1}$ and how the companies respond to the society demands over this issue. Thus, management implementation of $\mathrm{CSR}_{2}$ will produce $\mathrm{CSR}_{3}$ or CSP, the outcomes or results from the implementation of activities in $\mathrm{CSR}_{1}$ and $\mathrm{CSR}_{2}$ which give opportunity for measuring the success of overall firms' CSR based on the empirical available data.

The benefits of CSP are not only received by the targeted groups in the CSR programmes, moreover, it brings benefits to the companies which have proper implementation of CSR programmes in form positive financial performance for firms that invest in CSR activities as suggested by Bushee (2001). This relationship somewhat virtuous cycle, as described by Dean (1998) due to the situation either financial performance influenced by CSR activities or CSR activities influenced by firms' good financial performance. Nelling and Webb (2009) concur with relationship between CSR and financial performance, but they caution such relationship becomes weaker with the use of fixed effects Granger test. Recent study on CSP by Gregory et. al. (2016) suggest that CSP influences positively the firm's value, earnings persistence and acts as competitive edge. Their study were based on the 44 industries in the United Kingdom. Nevertheless, the unanswered question is how much should be spent or contributes for CSR programmes in order for the company to be seen as achieving their CSP is remained puzzled (Dean 1998). Sairally (2013) posits the suggested CSP components to be used when assessing the CSP of IFIs, as laid down by Carroll (1979): legal, ethical, economic and discretionary responsibilities.

Therefore, by exercising these four responsibilities, it signifies the fulfilment of CSR 1 and $\mathrm{CSR}_{2}$ conditions. Thus, from these four required responsibilities, it can be postulated that takaful operators seemed have acted as responsible corporate citizen which utilize various sources and consistently looking for avenues in order to contribute towards the society. If this really materializes in practise - takaful operators have conformed to the IFIs' societal objective. 


\section{RESEARCH METHOD}

This study has arranged structured interview sessions with the Chief Investment Officers and Heads of Investment of each of the eleven takaful operators in Malaysia. The Delphi-style technique was adopted when developing the interview questions - by gathering a panel of experts' opinions on the questions' draft. This is to ensure that the questions and scope of the study are relevant and capable of providing meaningful information for this research. The questions were developed in the form of a five-point Likert scale, addressing specific issues on CSP of takaful operators. In addition, information on takaful operators' CSR activities, zakat and tax payment were gathered from the companies' websites and annual report of takaful operators.

\section{FINDINGS ${ }^{\dagger}$}

Findings gathered from the structured interviews indicate that takaful operators measure their corporate social performance in two ways: zakat payment and CSR activities. Interestingly, the interviewees did not mention or consider the way their businesses being managed as part and parcel of their CSP. This is partly accurate since CSP for takaful operators is actually beyond zakat and charitable works. This situation substantiated Lu and Castka (2009) finding when they describe the confusion amongst the corporate sector in Malaysia when defining their companies' CSP scope. In contrast, Lu and Castka (2009) also did not delineate clearly in their study what can be constituted as CSR especially in the Malaysian context.

In the other end of the spectrum, the raison d'etre of the company can categorized as one of the items for the company's CSP. This is particularly important for institutions like takaful operators which regarded as religiously and commercially driven business entities. Therefore, they have to simultaneously serve these two needs without isolation to any of the objectives (Asutay 2008; Dar 2012). Thus, the presence of takaful operators in Malaysia for offering Shariah compliant insurance products and services are part of the companies' CSP - providing services required by the society - to satisfy commercial and religious needs. Previous literatures suggest that the CSP of IFIs can be summarized in two categories: business activities with society related agenda ${ }^{\ddagger}$ and actions purposely taken to fulfil the CSR activities. These two broad categories were explored in this study by having questions on how investment activities and the business model of takaful operator possibly help to achieve the societal objectives, as exhibited in the interview's five Likert-scale questions. As discussed earlier, Carroll (1979) breaks down the two categories into four components of CSP which a corporation expected to realize: economic; legal; ethical; and discretionary responsibilities. From the open-ended interview questions on CSR, the interviewees (as clarified earlier) mentioned that their takaful operators involved in various CSR activities for the community and every year they contribute for zakat payment. The CSR activities financed either from zakat's fund or from companies' dedicated budget for such programs. In addition for zakat, the payment either been made to the state Islamic council or they distribute them directly to the eight groups (asnaf) which qualified to receive zakat as mentioned in Holy Quran, with advised from their takaful operator's Shariah advisory committee.

\footnotetext{
$\dagger$ (Dummy takaful operators' names are used to maintain the confidential aspect of the information)

${ }^{\ddagger}$ This can be seen from raison d'etre of takaful operators to provide Shariah compliant insurance products.
} 
The delicate part is to measure how much is actually being spent or allocated for social programs yearly in order to assess the takaful operators' CSP. Most of the interviewees hardly able to brief (even rough estimation) agreeable percentages; except that citing zakat's amount $(2.5 \%$ from the prescribed zakat formula ${ }^{\S}$ ) as their bases. Likewise, zakat is only imposed to the shareholders' fund since the paid-up capital provided by them, if there is surplus (Abdullah et al. 2012). A simple comparison between takaful operators and conventional insurers will signify that in term of contribution to the nation in forms of taxes - takaful operator contributes more due to zakat payment (pseudo religious tax) and corporate tax compared to conventional insurers, albeit in term of amount the latter might contribute more. Likewise, it signifies that takaful operators have fulfilled the first CSR component: legal responsibility.

In another perspective, one may argue that zakat is a kind of compulsory religious tax in Islam and if there is any CSR tax impose on the conventional insurer; then the same situation will exist. Nonetheless, it is important to evoke the sacred philosophy and principles of Islamic financial institution in order to understand why such religious tax is imposed on takaful operators. Table 6(a) displays the yearly zakat contributions, tax payments and gross profits for five years, from 2010-2014. Prior to 2012, takaful operators prepared their financial statements according to the funds managed, which are: shareholders; family; and general funds. Accordingly, zakat and tax payment have contributed as low as MYR 100k to MYR 70 million to the country respectively; without coalescing specific CSR projects organized by the firms as displayed in Table 6(b). Tax is essential for every government in the world in order to run a country effectively for the citizen. Freedman (2003) emphasises that under CSR requirement, companies are expected to pay their tax to the government to show them good corporate citizen.

\begin{tabular}{|c|c|c|c|c|c|c|c|c|c|c|c|c|c|c|c|c|}
\hline & \multicolumn{5}{|c|}{$\begin{array}{l}\text { General Takaful Fund } \\
\text { (amount in MYR million) }\end{array}$} & \multicolumn{5}{|c|}{$\begin{array}{l}\text { Family Takaful Fund } \\
\text { (amount in MYR million) }\end{array}$} & \multicolumn{5}{|c|}{$\begin{array}{c}\text { Shareholder's Fund } \\
\text { (amount in MYR million) }\end{array}$} \\
\hline & & $\begin{array}{l}201 \\
0\end{array}$ & $\begin{array}{l}201 \\
1\end{array}$ & $\begin{array}{l}201 \\
2\end{array}$ & $\begin{array}{l}201 \\
3\end{array}$ & $\begin{array}{l}201 \\
4\end{array}$ & $\begin{array}{l}201 \\
0\end{array}$ & $\begin{array}{l}201 \\
1\end{array}$ & $\begin{array}{l}201 \\
2\end{array}$ & $\begin{array}{l}201 \\
3\end{array}$ & $\begin{array}{l}201 \\
4\end{array}$ & $\begin{array}{l}201 \\
0\end{array}$ & $\begin{array}{l}201 \\
1\end{array}$ & $\begin{array}{l}201 \\
2\end{array}$ & $\begin{array}{l}201 \\
3\end{array}$ & $\begin{array}{l}201 \\
4\end{array}$ \\
\hline \multirow{3}{*}{$\begin{array}{c}\text { TO1 } \\
\text { Berha } \\
\text { d }\end{array}$} & $\begin{array}{l}\text { Zaka } \\
t\end{array}$ & & & & & & & & & & & 0.1 & 0.1 & 0.1 & & \\
\hline & Tax & & 4 & 8 & & & & 2 & 9 & & & 4 & 7 & 2 & & \\
\hline & $\begin{array}{l}\text { Gros } \\
\text { s } \\
\text { Profi } \\
\mathrm{t} \\
\end{array}$ & & 9 & 20 & & & & 6 & 13 & & & -21 & 19 & 17 & & \\
\hline \multirow{3}{*}{$\begin{array}{c}\text { TO2 } \\
\text { Berha } \\
\text { d }\end{array}$} & $\begin{array}{l}\text { Zaka } \\
t\end{array}$ & & & & & & & & & & & 0.2 & 0.2 & 0.2 & 0.3 & \\
\hline & Tax & & 0.7 & 3 & 1 & & & 1 & 2 & 1 & & - & 3 & 3 & 3 & \\
\hline & $\begin{array}{l}\text { Gros } \\
\text { s } \\
\text { Profi } \\
t\end{array}$ & & 7 & 10 & 3 & & & 16 & 21 & 3 & & 7 & 15 & 15 & 16 & \\
\hline $\begin{array}{c}\text { TO3 } \\
\text { Berha }\end{array}$ & $\begin{array}{l}\text { Zaka } \\
t\end{array}$ & & & & & & & & & & & & & - & - & \\
\hline
\end{tabular}

\footnotetext{
${ }^{\S}$ In general, zakat can be calculated by using growth or working capital models. Growth Model: Owner's equity + Long term liability - fixed assets - intangible assets $+/$ - adjustments $=2.5 \% \mathrm{x}$ amount left for zakat $\mathrm{x} \%$ Muslim's share in the business. Capital working model: Current assets - current liability $+/$ - adjustments $=2.5 \% \mathrm{x}$ amount left for zakat x \% Muslim's share in the business. If partner is non-Muslim, then in both models, the share must be excluded from zakat.
} 


\begin{tabular}{|c|c|c|c|c|c|c|c|c|c|c|c|c|c|c|c|c|}
\hline \multirow[t]{2}{*}{ d } & Tax & & & & & & & & 0.8 & 1 & - & & & - & 0.3 & 0.3 \\
\hline & $\begin{array}{l}\text { Gros } \\
\mathrm{s} \\
\text { Profi } \\
\mathrm{t} \\
\end{array}$ & & & & & & & & -3 & -17 & -4 & & & -11 & -8 & -9 \\
\hline \multirow{3}{*}{$\begin{array}{c}\text { TO4 } \\
\text { Berha } \\
\text { d }\end{array}$} & $\begin{array}{l}\text { Zaka } \\
t\end{array}$ & & & & & & & & & & & & & - & - & \\
\hline & Tax & & & & & & & & 0.01 & 0.06 & & & & - & - & \\
\hline & $\begin{array}{l}\text { Gros } \\
\mathrm{s} \\
\text { Profi } \\
\mathrm{t} \\
\end{array}$ & & & & & & & & -1 & -0.3 & & & & -8 & -0.8 & \\
\hline \multirow{3}{*}{$\begin{array}{c}\text { TO5 } \\
\text { Berha } \\
\quad \text { d }\end{array}$} & $\begin{array}{l}\text { Zaka } \\
t\end{array}$ & - & - & - & - & - & - & - & - & - & - & 0.6 & 0.3 & 0.09 & 0.05 & 0.3 \\
\hline & Tax & - & 1 & 0.9 & 2 & 3 & 0.09 & 0.9 & 0.5 & 0.06 & 0.6 & - & 0.2 & 1 & 2 & 0.8 \\
\hline & $\begin{array}{l}\text { Gros } \\
\mathrm{s} \\
\text { Profi } \\
\mathrm{t} \\
\end{array}$ & $\begin{array}{c}- \\
0.07\end{array}$ & -6 & -2 & 7 & 9 & 30 & $\begin{array}{c}- \\
120\end{array}$ & -13 & 1 & 0.6 & 0.8 & -0.2 & $\begin{array}{c}- \\
0.01\end{array}$ & -5 & -3 \\
\hline \multirow{3}{*}{$\begin{array}{c}\text { TO6 } \\
\text { Berha } \\
\text { d }\end{array}$} & $\begin{array}{l}\text { Zaka } \\
t\end{array}$ & & & & & & & & & & & & & 0.3 & 0.3 & \\
\hline & Tax & & & & & & & & 1 & 2 & & & & 8 & 11 & \\
\hline & $\begin{array}{l}\text { Gros } \\
\mathrm{s} \\
\text { Profi } \\
\mathrm{t} \\
\end{array}$ & & & 16 & 8 & & & & 210 & 139 & & & & 40 & 23 & \\
\hline \multirow{3}{*}{$\begin{array}{c}\text { TO7 } \\
\text { Berha } \\
\text { d }\end{array}$} & $\begin{array}{l}\text { Zaka } \\
t\end{array}$ & & & & & & & & & & & & & & & \\
\hline & Tax & & & & & & & & & & & & 3 & & 0.8 & \\
\hline & $\begin{array}{l}\text { Gros } \\
\text { s } \\
\text { Profi } \\
t \\
\end{array}$ & & & & & & & & & & & & -15 & -18 & -3 & \\
\hline \multirow{3}{*}{$\begin{array}{c}\text { TO8 } \\
\text { Berha } \\
\text { d }\end{array}$} & $\begin{array}{l}\text { Zaka } \\
t\end{array}$ & & & & & & & & & & & 0.1 & 0.4 & 0.4 & 0.8 & \\
\hline & Tax & 0.4 & 0.5 & & & & 0.1 & 0.4 & 0.2 & & & 6 & 8 & 10 & 12 & \\
\hline & $\begin{array}{l}\text { Gros } \\
\mathrm{s} \\
\text { Profi } \\
\mathrm{t} \\
\end{array}$ & 2 & 2 & & & & 102 & 139 & 102 & & & 20 & 28 & 32 & 41 & \\
\hline \multirow{3}{*}{$\begin{array}{c}\text { TO9 } \\
\text { Berha } \\
\quad \text { d }\end{array}$} & $\begin{array}{l}\text { Zaka } \\
t\end{array}$ & & & & & & & & & & & 0.4 & 0.4 & 0.4 & 0.4 & \\
\hline & Tax & 3 & 1 & 2 & 18 & & 3 & 3 & 4 & 4 & & 5 & 5 & 5 & 8 & \\
\hline & $\begin{array}{l}\text { Gros } \\
\mathrm{s} \\
\text { Profi } \\
\mathrm{t} \\
\end{array}$ & 14 & 6 & 13 & 25 & & 200 & 241 & 256 & 63 & & 15 & 14 & 13 & 19 & \\
\hline \multirow{3}{*}{$\begin{array}{c}\text { T010 } \\
\text { Berha } \\
\text { d }\end{array}$} & $\begin{array}{l}\text { Zaka } \\
t\end{array}$ & & & & & & & & & & & 4 & 4 & 8 & 8 & \\
\hline & Tax & & 10 & & & & & 29 & & & & 43 & 20 & 71 & 70 & \\
\hline & $\begin{array}{l}\text { Gros } \\
\mathrm{s} \\
\text { Profi } \\
\mathrm{t}\end{array}$ & 91 & 66 & & & & 202 & 182 & & & & 106 & 67 & 205 & 267 & \\
\hline \multirow{3}{*}{$\begin{array}{c}\text { TO11 } \\
\text { Berha } \\
\text { d }\end{array}$} & $\begin{array}{l}\text { Zaka } \\
t\end{array}$ & & & & & & & & & & & 0.4 & 0.5 & 1 & 2 & \\
\hline & Tax & & & & & & & & & & & 43 & 22 & 25 & 43 & \\
\hline & $\begin{array}{l}\text { Gros } \\
\text { s } \\
\text { Profi } \\
\text { t }\end{array}$ & & & & & & & & & & & 93 & 94 & 127 & 178 & \\
\hline
\end{tabular}




\section{Table 6(a): Takaful Operators' Gross Profit, Zakat Contributions and Tax Payments}

Move on to the next component which is ethical responsibility as suggested by Carroll (1979), it is appropriate to denote that takaful operators in Malaysia involved in various CSR activities voluntarily and their charity works were noticeable especially during Ramadhan (the fasting month) due to religious sentiment on that holy month. The number of CSR activities of takaful operators in Malaysia are displayed in Table 6(b) based on the information gathered from the companies' websites from 2010 - 2014. However, total money spent for the activities are not available except for TO11 Berhad - the company spent nearly MYR 1 million every year for CSR activities. For the rest of takaful operators, some only listing their CSR projects, but nearly half of them did not inform any CSR activities in their websites and annual reports.

\begin{tabular}{|c|c|c|c|c|c|}
\hline \multirow{2}{*}{$\begin{array}{c}\text { Takaful } \\
\text { Operators }\end{array}$} & \multicolumn{5}{|c|}{ Number of CSR Activities and Budget Spent } \\
\hline & 2010 & 2011 & 2012 & 2013 & 2014 \\
\hline TO1 Berhad & 2 & 2 & 2 & 2 & 2 \\
\hline TO2 Berhad & $\mathrm{n} / \mathrm{a}$ & $\mathrm{n} / \mathrm{a}$ & $\mathrm{n} / \mathrm{a}$ & $\mathrm{n} / \mathrm{a}$ & 4 \\
\hline TO3 Berhad & 1 & $\mathrm{n} / \mathrm{a}$ & $\mathrm{n} / \mathrm{a}$ & $\mathrm{n} / \mathrm{a}$ & $\mathrm{n} / \mathrm{a}$ \\
\hline TO4 Berhad & $\mathrm{n} / \mathrm{a}$ & $\mathrm{n} / \mathrm{a}$ & $\mathrm{n} / \mathrm{a}$ & $\mathrm{n} / \mathrm{a}$ & $\mathrm{n} / \mathrm{a}$ \\
\hline TO5 Berhad & $\mathrm{n} / \mathrm{a}$ & $\mathrm{n} / \mathrm{a}$ & $\mathrm{n} / \mathrm{a}$ & $\mathrm{n} / \mathrm{a}$ & 1 \\
\hline TO6 Berhad & $\mathrm{n} / \mathrm{a}$ & $\mathrm{n} / \mathrm{a}$ & $\mathrm{n} / \mathrm{a}$ & $\mathrm{n} / \mathrm{a}$ & $\mathrm{n} / \mathrm{a}$ \\
\hline TO7 Berhad & 1 & 2 & 1 & 1 & 3 \\
\hline TO8 Berhad & 1 & 2 & 4 & 2 & $\mathrm{n} / \mathrm{a}$ \\
\hline TO9 Berhad & 7 & 19 & 28 & 28 & 17 \\
\hline TO10 Berhad & $\mathrm{n} / \mathrm{a}$ & $\mathrm{n} / \mathrm{a}$ & $\mathrm{n} / \mathrm{a}$ & $\mathrm{n} / \mathrm{a}$ & $\mathrm{n} / \mathrm{a}$ \\
\hline T011 Berhad & $\begin{array}{c}6 \\
\text { (MYR 2.5mil) }\end{array}$ & $\begin{array}{c}5 \\
\text { (MYR 1mil) }\end{array}$ & $\begin{array}{c}12 \\
\text { (MYR 1mil) }\end{array}$ & $\begin{array}{c}9 \\
\text { (MYR 1mil) }\end{array}$ & 4 \\
\hline
\end{tabular}

Table 6(b): Takaful Operators' CSR Activities \& Budget Spent, accessed from companies' websites as at 7 Jan 2015

The next component is economic responsibility which previous studies have covered in-depth on this in form financial performance based on the efficiency management of cost, structural form and technological effect (Saad et al. 2006; Kader, Adams \& Hardwick 2010; Ismail, Alhabshi \& Bacha 2011; Saad \& Idris 2011). In other words, each year takaful operators have performed this responsibility well by achieving business growths and profits for their principals: shareholders and takaful contributors, as shown in Table 6(a).

The last component is discretionary responsibility (Carroll 1979), which defined by Gitman and McDaniel (2008) as the endeavour took by the firms to fulfil the early three components (legal, economic and ethical responsibilities) and move to the highest level of philanthropy by ensuring the company's business model and its activities meet able to serve the society. This part may sound utopia or difficult to achieve. However, looking back at the early three responsibilities under CSR, takaful operators can be regarded have achieved and fulfilled them. Thus, for 
discretionary responsibility, arguably takaful operators have managed to achieve it. Even though philanthropically, the waqf (endowment) model looks preferable since it has the capacity to reach and deliver better social services, but the currently adopted wakalah version of takaful model also capable to fulfil its social obligation within its spectrum. It is noteworthy to mention that while waqf model established solely for charitable, in the other side, wakalah model shows how commercial features enjoined with social obligations able to serve both needs: profit and social welfare.

It is understandable that there are groups of people who critics and claims that such social performance is not sufficient for Islamic financial institution. The criticisms normally address to the Islamic banks. As for the takaful operators, although they share some similarities with the Islamic banks, however in term of operational wise they are different.

All things considered, it is convenient to remark that takaful operators have fulfilled their $\mathrm{CSR}_{1}$ and $\mathrm{CSR}_{2}$. However, the $\mathrm{CSR}_{3}$ component is hardly measured empirically in this study as it requires longer time frame and more active involvement from takaful operators in order to track their CSR activities and deriving the positive outcomes resulted from such activities.

Nevertheless, it is appropriate to denote in general such activities have given benefits to the receivers based on the information and news retrieved from newspapers and companies' websites in relations to their CSR activities, also from the local Islamic councils that manage zakat fund.

\section{CONCLUSION}

Takaful operators have achieved their CSP within the limited features of wakalah takaful model. This aspect can be derived from the findings presented in Table 6(a) on zakat contributions and tax payment, and Table 6(b) on the number of CSR activities and budget spent for the programs. The figures displayed indicate that takaful operators' CSP is a "profit driven social programs." In other words, the profits derived from the business were used to conduct social programs in forms of zakat contributions, tax payment and CSR activities. Nevertheless, this only represents part of the broad social responsible aspect which the companies have done. Another important aspect which is rarely considered and mentioned under the takaful operators' social responsible theme is their raison d'etre or business agenda. It should be emphasised that takaful operators were established to continue the classical notion of takaful ${ }^{* *}$ operation; but in a different setting, as a result of the needs to embrace modern corporation concept. Nevertheless, the main purpose is remained similar which is to offer alternative to the Muslims to be able to utilize insurance services which comply with Shariah (Husin \& Rahman 2013; Souiden \& Jabeur 2015), and to eliminate financial exclusion due to religious constraint (Coolen-Maturi 2013). This noble objective is stipulated in the white paper of steering committee comprising 20 experts in the field which was formed by the Malaysian government to study the feasibility of Islamic finance in Malaysia in 1981 (Laldin 2008).

Therefore, from the discussion above, this study views that it has managed to assess takaful operators' corporate social performance (CSP) from four angles as suggested in previous literature: economic; legal; ethical; and discretionary responsibilities. Moreover, takaful operators have fulfilled expectations bestowed upon them as Islamic financial institutions (IFIs)

\footnotetext{
** Takaful was initially formed based on brotherhood and mutual assistance in helping each other in the event of calamity.
} 
by delivering their CSP well and attaining profit every year - socially responsible and financially profitable.

\section{REFERENCES}

Abdullah, M, Amanbayev, Y, Omer, GS \& Elobied, A 2012, An overview of takaful in Malaysia, INCEIF, Kuala Lumpur.

\section{Al-Quran 5:2 Surah Al-Maidah.}

Alhabshi, SO \& Razak, SH 2011, 'Takaful insurance: concept, history and development challenges', in Ariff, M \& Iqbal, M (eds), The Foundations of Islamic Banking : Theory, Practice and Education, Edward Elgar Publishing, Cheltenham.

Ali, A, Al-Aali, A \& Al-Owaihan, A 2012, 'Islamic perspectives on profit maximization', Journal of Business Ethics, 2012/11/01, pp. 1-9.

Asutay, M 2008, 'Islamic banking and finance: social failure', New Horizon: Global Perspective on Islamic Banking and Insurance.

Bakar, MD 2011, 'Shariah principles governing takaful models', in Archer, S, Karim, RAA \& Nienhaus, V (eds), Takaful Islamic Insurance : Concepts and Regulatory Issues, 1 edn, Wiley, Hoboken.

Bushee, BJ 2001, 'Do institutional investors prefer near-term earnings over long-run value?', Contemporary Accounting Research, vol. 18, no. 2, pp. 207-246.

Cantori, L \& Lowrie, A 1992, 'Islam, democracy, the state and the west', Middle East Policy, vol. 1, pp. 49-50.

Carroll, AB 1979, 'A three-dimensional conceptual model of corporate performance', Academy of Management Review, vol. 4, no. 4, pp. 497-505.

Çizakça, M 2011, Islamic capitalism and finance: origins, evolution and the future, Edward Elgar Publishing,

Coolen-Maturi, T 2013, 'Islamic insurance (takaful): demand and supply in the UK', International Journal of Islamic and Middle Eastern Finance and Management, vol. 6, no. 2, pp. 87-104.

Dar, H 2012, 'Identity crisis: Islamic banking - in search of a lost soul', viewed 14 January 2015, $<$ http://islam.ru/en/content/story/identity-crisis-islamic-banking-search-lost-soul $>$. 
Dean, KL 1998, 'The chicken and the egg revisited: Ties between corporate social performance and the financial bottom line', Academy of Management Perspectives, vol. 12, no. 2, pp. 99-100.

Engku Ali, ER, Odierno, HS \& Ismail, A 2008, Essential guide to takaful (Islamic Insurance), CERT Publications Sdn. Bhd, Kuala Lumpur.

Frederick, W 1994, 'From CSR1 to CSR2', Business and Society, vol. 33, no. 2, p. 150.

Freedman, J 2003, 'Tax and corporate responsibility', Tax Journal, vol. 695, no. 2, pp. 1-4.

Gitman, L \& McDaniel, C 2008, The future of business: the essentials, Cengage Learning,

Gönülal, SO 2012, Takaful and mutual insurance : alternative approaches to managing risks, World Bank Publications, Washington, $<\underline{\text { http://UNISA.eblib.com.au/patron/FullRecord.aspx?p=1069840>. }}$.

Gregory, A, Whittaker, J \& Yan, X 2016, 'Corporate social performance, competitive advantage, earnings persistence and firm value', Journal of Business Finance \& Accounting, vol. 43, no. $1 \& 2$.

Hasan, Z 2014, Islamic banking and finance: an integrative approach, Oxford University Press, Kuala Lumpur.

Htay, SNN \& Zaharin, HR 2012, 'Critical analysis on the choice of takaful (Islamic Insurance) operating models in Malaysia', World, vol. 2, no. 2, pp. 112-127.

Husin, MM \& Rahman, AA 2013, 'What drives consumers to participate into family takaful schemes? A literature review', Journal of Islamic Marketing, vol. 4, no. 3, pp. 264-280.

ING Website 2012, Newsroom, AIA PublicTakaful, viewed 29 May, $<$ http://www.ing.com/Newsroom/All-news/Press-releases/PR/ING-to-sell-insurancebusinesses-in-Malaysia-to-AIA.htm>.

Ismail, N, Alhabshi, SO \& Bacha, O 2011, Cost Efficiency and Investment Performance: Mutual and Stock Form in Malaysian Insurance Industry, Working paper, International Centre for Education in Islamic Finance (INCEIF), Malaysia.

Kader, HA, Adams, M \& Hardwick, P 2010, 'The cost efficiency of takaful insurance companies*', Geneva Papers on Risk \& Insurance, vol. 35, no. 1, pp. 161-181.

Kuran, T 2012, The Long Divergence, Princeton University Press, United States of America.

Laldin, MA 2008, 'Islamic financial system: the Malaysian experience and the way forward', Humanomics, vol. 24, no. 3, pp. 217-238. 
Lu, JY \& Castka, P 2009, 'Corporate social responsibility in Malaysia - experts' views and perspectives', Corporate Social Responsibility and Environmental Management, vol. 16, no. 3, pp. 146-154.

Malaysian Takaful Association 2014, Malaysian Takaful Dynamics, Malaysian Takaful Association and Ernst \& Young Kuala Lumpur.

Metwally, MM 1997, 'Economic consequences of applying Islamic principles in Muslim societies', International Journal of Social Economics, vol. 24, no. 7, pp. 941-957.

Mohd Kassim, ZA 2012, The primary insurance models, World Bank Publications, Washington.

Nelling, E \& Webb, E 2009, 'Corporate social responsibility and financial performance: the "virtuous circle" revisited', Review of Quantitative Finance and Accounting, vol. 32, no. 2, pp. 197-209.

Pamuk, Ş 2004, 'Institutional change and the longevity of the Ottoman Empire, 1500-1800', Journal of Interdisciplinary History, vol. 35, no. 2, pp. 225-247.

Raghib, H 1995, 'Islamic values and beliefs and their impact on marketing policy: Comparative analysis study', Management in Islam, pp. 307-355.

Saad, NM, Majid, MSA, Yusof, RM, Duasa, J \& Rahman, A 2006, 'Measuring Efficiency of Insurance and Takaful Companies in Malaysia Using Data Envelopment Analysis (DEA)', Review of Islamic Economics, vol. 10, no. 2, p. 5.

Saad, NM \& Idris, NEH 2011, 'Efficiency of life insurance companies in Malaysia and Brunei: a comparative analysis'.

Sairally, BS 2013, 'Evaluating the corporate social performance of Islamic financial institutions: an empirical study', International Journal of Islamic and Middle Eastern Finance and Management, vol. 6, no. 3, pp. 238-260.

Siddiqi, MN 1981, Muslim economic thinking: a survey of contemporary literature, International Centre for Research in Islamic Economics, King Abdul Aziz University,

Siddiqui, F \& Hunt-Ahmed, K 2013, 'Takaful', in Hunt-Ahmed, K (ed), Contemporary Islamic Finance, John Wiley \& Sons, Inc., pp. 203-213.

Souiden, N \& Jabeur, Y 2015, 'The impact of Islamic beliefs on consumers' attitudes and purchase intentions of life insurance', International Journal of Bank Marketing, vol. 33, no. 4 , pp. 423-441.

Swartz, NP \& Coetzer, P 2010, 'Takaful: An Islamic Insurance Instrument', Journal of Development and Agricultural Economics, vol. 2, no. 10, pp. 333-339. 
The World Takaful Report 2014, Growth momentum continues, Ernst \& Young.

Wahab, ARA, Lewis, MK \& Hassan, MK 2007, 'Islamic takaful: business models, shariah concerns, and proposed solutions', Thunderbird International Business Review, vol. 49, no. 3, pp. 371-396.

Wilson, R 2008, 'Islamic economics and finance', World Economics, vol. 9, no. 1, p. 177. 